\title{
ФАКТОРНА МОДЕЛЬ РОЗВИТКУ РУХОВОЇ ФУНКЦІї У ХЛОПЧИКІВ МОЛОДШИХ КЛАСІВ
}

\author{
Мірошниченко Д. Т. \\ Харківський національний економічний університет імені Семена Кузнеця
}

\author{
DOI: $10.17309 /$ tmfv.2014.4.1114
}

\begin{abstract}
Анотація. Мета дослідження - визначити факторну модель розвитку рухової функції у хлопчиків молодших класів. Методи й організація дослідження. В дослідженні використані такі методи дослідження як аналіз наукової та методичної літератури, педагогічні спостереження, тестування рухової підготовленості, ймовірнісний підхід до оцінки процесу навчання, методи математичної статистики. У дослідженні прийняли участь хлопчики 2 класу - 38 чоловік, 3 класу - 42 чоловік, 4 класу -48 чоловік.

Висновки. У факторній моделі рухової функції у хлопців виділяються: процеси навчання і розвитку рухових здібностей (другий клас); процеси навчання і розвитку силових здібностей (третій клас); процеси навчання і розвитку силових і координаційних здібностей (четвертий клас).

Найбільшу інформативність для оцінки розвитку рухової функції у хлопчиків мають: другий клас - рівень навченості акробатичних вправ $(0,848 ; 0,774 ; 0,809)$; третій клас - рівень розвитку власне силових здібностей: тест «Підтягування у змішаному висі на канаті (разів)» $(0,941)$, рівень навченості вправам: «Підйом переворотом в упор махом однією» $(0,910)$, «Міст із положення лежачи» $(0,860)$; четвертий клас - рівень навченості вправам «Лазіння по канату у 2 прийоми» $(0,939)$, «Лазіння по канату у 3 прийоми» $(0,939)$, «Підйом переворотом в упор махом однією (0,745), а також результати тестів: № 7 «Підтягування у змішаному висі на канаті» $(0,787)$, № 10 «Час збереження стійкого положення - стійка на одній нозі з закритими очима» $(0,723)$.

Ключові слова. Хлопчики, молодші класи, навчання, фізичні вправи.
\end{abstract}

Актуальність. У сучасних умовах зниження рухової активності школярів, низькій опірності їх організму до захворювань постає проблема формування рухової функції у дітей і підлітків (Носко M.О., 2001; Бальсевич B.К., 2000; Cieślicka M., Muszkieta R., Napierała M., Żukow W. , 2009; Круцевич Т.Ю., Безверхня Г. В., 2010; Васьков Ю. В., 2010, 2012; Cieślicka M., Dix B., Napierała M., Żukow W., 2012; Martins Júlio, Honório Samuel, Cardoso João, Duarte Luís, 2014; Andrea Piccinno, Dario Colella, 2014).

На ефективність формування рухової функції у дітей і підлітків впливає процес розвитку рухових здібностей і навчання фізичних вправ. Рухова функція розглядається як результат інтеграції рухових здібностей у рухових навичках, як рішення нового рухового завдання найбільш раціональним способом (Худолій, О.М., Марченко C.I., 2007; Худолій О. М., 2009; Худолій О.М., Тітаренко А.А., 2010; Худолій О.М., Іващенко О.В., Черненко С.О., 2013; Худолій О.М., Іващенко О.В., 2013, 2014).

Отже, розгляд факторної моделі розвитку рухової функції школярів молодших класів $\epsilon$ актуальним.

Аналіз останніх досліджень і публікацій. Науковому обгрунтуванню системи фізичного виховання школярів присвячені роботи Васькова Ю.В. (2010, 2012), Круцевич Т.Ю. (2006), Москаленко Н.В., Гонтаровської Н.Б. (2006). У дослідженнях

(c) Мірошниченко Д. Т., 2014
Іващенко О.В. (1988), Карпунець Т. В. (2001), Miрошниченко Д.Т. (2007), розглянута методика навчання фізичним вправам шкільної програми, для учнів молодших класів запропоновані технологічні підходи до навчання акробатичним вправам і лазінню по канату. У роботах Худолія О.М. (2009), Іващенко О.В. (1988), Худолія О.М., Іващенко О.В. (2014) обгрунтовані закономірності формування рухових навичок у юних гімнастів.

Закономірності розвитку рухових здібностей у дітей молодшого шкільного віку розглянуті у роботах Ляха В.I. (2000), Худолія О.М., Марченко С.I. (2007), Марченко С. I. (2007, 2008, 2009, 2010), Худолія О.М., Іващенко О.В. $(2013,2014)$.

Однак, у доступній науковій літературі недостатньо приділяється уваги дослідженню цілісності процесів розвитку рухових здібностей і формування рухових навичок у школярів молодших класів.

Зв'язок роботи з науковими програмами, планами, темами. Дослідження виконано згідно плану науково-дослідної роботи Міністерства освіти і науки, молоді і спорту України за темою 13.04 «Моделювання процесу навчання та розвитку рухових здібностей у дітей і підлітків» (2013-2014рр.) (номер державної реєстрації 0113U002102).

\section{Матеріал і методи.}

Мета дослідження - визначити факторну модель розвитку рухової функції у хлопчиків молодших класів. 
Методи й організація дослідження. В дослідженні використані такі методи дослідження як аналіз наукової та методичної літератури, педагогічні спостереження, тестування рухової підготовленості, ймовірнісний підхід до оцінки процесу навчання, методи математичної статистики.

У плануванні дослідження використані концептуальні підходи до організації наукових досліджень у фізичному вихованні і спорті, що були викладені у роботах Ашмаріна Б.А. (1978), Круцевич Т.Ю. (1985), Філіна В.П., Ровного А.С. (1992), Худолія О.М., Іващенко О.В. (2014).

У програму тестування ввійшли загальновідомі тести (Лях В.Й., 2000; Сергієнко Л.П., 2001; Худолій О.М., Іващенко О. В., 2011). У дослідженні реєструвалися показники зросту (см), маси тіла (кг), а також результати в тестах № 3 «Стрибок в довжину з місця (см)», № 4 «Біг на середні та довгі дистанції. Біг 300 метрів (с)», № 5 «Спринтерський біг 30 метрів з високого старту (с)», № 6 «Нахил тулуба вперед із положення сидячи (см)», № 7 «Підтягування у змішаному висі на канаті (разів)», № 8 «Човниковий біг $4 \times 9$ метрів (с)», № 9 «Вправи на поєднання рухів руками, тулубом і ногами (в балах)», № 10 «Час збереження стійкого положення - стійка на одній нозі з закритими очима (c)»,
№ 11 «Ходьба по прямій лінії після 5 обертів (відхилення в см)».

Таблиия 1

Гімнастичні вправи, виконання яких контролювалося в експерименті

\begin{tabular}{|l|l|l|}
\hline Клас & Назва вправи & $\begin{array}{l}\text { Кількість } \\
\text { спроб (n) }\end{array}$ \\
\hline 2 клас & $\begin{array}{l}\text { перекид уперед; } \\
\text { перекид назад; } \\
\text { стійка на лопатках зігнувши ноги }\end{array}$ & 5 \\
\hline 3 клас & стійка на лопатках & 5 \\
& міст із положення лежачи \\
& підйом переворотом в упор махом од- \\
& нією & 5 \\
\hline 4 клас & $\begin{array}{l}\text { лазіння по канату у 2 прийоми } \\
\text { лазіння по канату у 3 прийоми } \\
\text { підйом переворотом в упор махом од- } \\
\text { нією }\end{array}$ & $3(3$ м) \\
\hline
\end{tabular}

У школярів молодших класів реєструвався рівень навченості гімнастичним вправам. Коефіцієнт визначався за формулою: $\mathrm{p}=(\mathrm{m} / \mathrm{n})^{\star} 100$, де $\mathrm{p}-\mathrm{pi}$ вень навченості, $\mathrm{m}$ - кількість успішно виконаних вправ, $\mathrm{n}$ - загальна кількість спроб на виконання вправи. У таблиці 1 наведені вправи, виконання яких контролювалося в експерименті.

Таблиия 2

Факторна модель розвитку рухової функиї у хлопців 2 класу $(n=38)$.

\begin{tabular}{|c|c|c|c|c|c|c|}
\hline \multirow{2}{*}{ № $3 / \Pi$} & \multirow{2}{*}{ Назва тесту } & \multicolumn{4}{|c|}{ Компонента } & \multirow{2}{*}{$\mathrm{h}^{2}$} \\
\hline & & 1 & 2 & 3 & 4 & \\
\hline 1 & Зріст, см & & & ,872 & & ,782 \\
\hline 2 & Маса тіла, кг & & & ,930 & & ,873 \\
\hline 3 & Стрибок у довжину з місця (см) & & ,783 & & & 654 \\
\hline 4 & Біг 300 метрів (с) & ,320 &,- 763 & & & ,691 \\
\hline 5 & Біг 30 метрів з високого старту (c) & & & & ,777 & ,629 \\
\hline 6 & Нахил тулуба вперед із положення сидячи (см) & & & & ,770 & ,602 \\
\hline 7 & Підтягування у змішаному висі на канаті (разів) & & ,826 & & & ,742 \\
\hline 8 & Човниковий біг $4 \times 9$ метрів (с) & & & & ,764 & ,688 \\
\hline 9 & $\begin{array}{l}\text { Вправи на поєднання рухів руками, тулубом і ногами } \\
\text { (в балах) }\end{array}$ & ,632 & & & & ,430 \\
\hline 10 & $\begin{array}{l}\text { Час збереження стійкого положення - стійка на од- } \\
\text { ній нозі з закритими очима (c) }\end{array}$ & & & ,607 & & ,417 \\
\hline 11 & $\begin{array}{l}\text { Ходьба по прямій лінії після } 5 \text { обертів (відхилення в } \\
\text { см) }\end{array}$ &,- 628 & ,334 & & &, 584 \\
\hline 12 & Перекид уперед & ,905 & & & & ,848 \\
\hline 13 & Перекид назад & ,853 & & & & ,774 \\
\hline 14 & Стійка на лопатках зігнувши ноги & ,825 & & & & ,809 \\
\hline & Повна пояснена дисперсія, \% & 22,872 & 15,500 & 15,374 & 14,264 & 68,01 \\
\hline
\end{tabular}


Факторна модель розвитку рухової функиії у хлопијів 3 класу (n=42).

\begin{tabular}{|c|c|c|c|c|c|c|c|}
\hline \multirow{2}{*}{$\begin{array}{l}\text { № } \\
3 / \Pi\end{array}$} & \multirow{2}{*}{ Назва тесту } & \multicolumn{5}{|c|}{ Компонента } & \multirow{2}{*}{$\mathrm{h}^{2}$} \\
\hline & & 1 & 2 & 3 & 4 & 5 & \\
\hline 1 & Зріст, см & & & & ,855 & & ,771 \\
\hline 2 & Маса тіла, кг & & & & ,885 & & ,833 \\
\hline 3 & Стрибок у довжину з місця (см) & & 418 &, 517 & & ,333 & 609 \\
\hline 4 & Біг 300 метрів (c) & & & ,663 & & & 457 \\
\hline 5 & Біг 30 метрів з високого старту (c) & & & ,684 & & & ,627 \\
\hline 6 & Нахил тулуба вперед із положення сидячи (см) & ,883 & & & & & ,818 \\
\hline 7 & Підтягування у змішаному висі на канаті (разів) & & ,960 & & & & 941 \\
\hline 8 & Човниковий біг $4 \times 9$ метрів (c) & ,637 & & & & &, 527 \\
\hline 9 & $\begin{array}{l}\text { Вправи на поєднання рухів руками, тулубом і ногами } \\
\text { (в балах) }\end{array}$ & ,374 & & & & & ,229 \\
\hline 10 & $\begin{array}{l}\text { Час збереження стійкого положення - стійка на одній } \\
\text { нозі з закритими очима (c) }\end{array}$ & & &, 535 & &,- 581 & ,699 \\
\hline 11 & Ходьба по прямій лінії після 5 обертів (відхилення в см) & & & & & ,761 & ,615 \\
\hline 12 & Стійка на лопатках & & & ,709 & & & ,649 \\
\hline 13 & Міст із положення лежачи &, 894 & & & & & 860 \\
\hline 14 & Підйом переворотом в упор махом однією & & ,941 & & & & ,910 \\
\hline & Повна пояснена дисперсія, \% & 16,673 & 15,401 & 15,330 & 12,096 & 8,673 & 68,174 \\
\hline
\end{tabular}

У дослідженні прийняли участь хлопчики 2 класу - 38 чоловік, 3 класу - 42 чоловік, 4 класу - 48 чоловік.

Результати дослідження. Результати факторного аналізу наведені у таблицях 2-9.

Для визначення факторної моделі розвитку рухової функціїу хлопчиків 2 класу був проведений факторний аналіз за 14 показниками тестування. У процесі аналізу виділилося чотири фактори, які пояснюють 68,01\% сумарної дисперсії.

Фактор 1 має найбільшу інформативність $(22,872 \%)$. Фактор корелює 3 рівнем навченості акробатичних вправ $(0,905 ; 0,853 ; 0,825)$ та результатими тестів «Вправи на поєднання рухив руками, тулубом и ногами» $(0,632)$, «Ходьба по прямій лінії після 5 обертів» $(-0,628)$. Фактор отримав назву «здатність до навчання фізичним вправам».

Фактор 2 (інформативність 15,5\%) має найбільшу кореляцію з швидкісно-силовою підготовленістю (тест № 3 «Стрибок у довжину 3 місця», 0,783), власне силовою підготовленістю (тест №7 «Підтягування у змішаному висі на канаті», 0,826), витривалістю (тест № 4 «Біг 300 м», -0,763). Фактор комплексний і характеризує прояв сили і витривалості.

Фактор 3 (інформативність 15,374\%) має найбільшу кореляцію з показниками фізичного розвитку (зріст, 0,872; маса тіла, 0,980). Фактор отримав назву фізичний розвиток.

Фактор 4 (інформативність 14,264\%) найбільшу кореляцію має з результатами тестів «Біг 30 м»
$(0,777)$, «Нахил тулуба вперед із положення сидячи» $(0,770)$, «Човниковий біг $4 \times 9$ м» $(0,764)$. Він характеризує розвиток прудкості, гнучкості і спритності.

Аналіз спільностей $\left(\mathrm{h}^{2}\right)$ показав, що найбільшу інформативність для оцінки розвитку рухової функції хлопчиків другого класу має рівень навченості акробатичних вправ $(0,848 ; 0,774 ; 0,809)$. Отже, у факторній моделі рухової функції у хлопців другого класу виділяються процеси навчання і розвитку рухових здібностей.

Для визначення факторної моделі розвитку рухової функціїу хлопчиків 3 класу був проведений факторний аналіз за 14 показниками тестування. У процесі аналізу виділилося п’ять факторів, які пояснюють 68,174 \% сумарної дисперсії.

Фактор 1 має найбільшу інформативність $(16,673 \%)$. Фактор корелює 3 рівнем навченості акробатичної вправи «Міст із положення лежачи» $(0,894)$ та результатими тестів «Нахил тулуба вперед із положення сидячи» $(0,883)$, «Човниковий біг $4 \times 9$ метрів» $(0,637)$. Фактор отримав назву «здатність до навчання фізичним вправам».

Фактор 2 (інформативність 15,401\%) має найбільшу кореляцію з результатами тесту №7 «Підтягування у змішаному висі на канаті» $(0,960)$, рівнем навченості вправі «Підйом переворотом в упор махом однією» $(0,941)$. Фактор характеризує здатність до навчання гімнастичним вправам.

Фактор 3 (інформативність 15,330\%) має найбільшу кореляцію 3 рівнем навченості вправі 
Факторна модель розвитку рухової функизї у хлопијів 4 класу (n=48).

\begin{tabular}{|c|c|c|c|c|c|c|c|}
\hline \multirow{2}{*}{$\begin{array}{c}\text { № } \\
3 / \Pi \\
\end{array}$} & \multirow{2}{*}{ Назва тесту } & \multicolumn{5}{|c|}{ Компонента } & \multirow{2}{*}{$\mathrm{h}^{2}$} \\
\hline & & 1 & 2 & 3 & 4 & 5 & \\
\hline 1 & Зріст, см & ,451 &, 567 & & & &, 592 \\
\hline 2 & Маса тіла, кг & & ,748 & & & & ,683 \\
\hline 3 & Стрибок у довжину з місця (см) & &,- 534 & 480 & & & 607 \\
\hline 4 & Біг 300 метрів (с) & & ,798 & & & & 689 \\
\hline 5 & Біг 30 метрів з високого старту (с) & & 695 & & & &, 506 \\
\hline 6 & Нахил тулуба вперед із положення сидячи (см) &,- 405 & &, 434 & 489 & & ,655 \\
\hline 7 & Підтягування у змішаному висі на канаті (разів) & & & & &, 853 &, 787 \\
\hline 8 & Човниковий біг 4×9 метрів (c) & & &,- 803 & & & 688 \\
\hline 9 & $\begin{array}{l}\text { Вправи на поєднання рухів руками, тулубом і ногами } \\
\text { (в балах) }\end{array}$ & & & ,760 &,- 309 & & ,675 \\
\hline 10 & $\begin{array}{l}\text { Час збереження стійкого положення - стійка на одній } \\
\text { нозі з закритими очима (c) }\end{array}$ & & & &,- 800 & & ,723 \\
\hline 11 & Ходьба по прямій лінії після 5 обертів (відхилення в см) & & & & ,784 & & 659 \\
\hline 12 & Лазіння по канату у 2 прийоми & 921 & & & & & ,939 \\
\hline 13 & Лазіння по канату у 3 прийоми & 921 & & & & & 939 \\
\hline 14 & Підйом переворотом в упор махом однією & ,466 & & & &, 718 & ,745 \\
\hline & Повна пояснена дисперсія, \% & 17,187 & 16,962 & 12,733 & 12,118 & 11,608 & 70,608 \\
\hline
\end{tabular}

«Стійка на лопатках» (0,709), результатами тестів № 5 «Біг 30 метрів 3 високого старту» $(0,684)$, № 4 «Біг 300 метрів» (0,663). Фактор характеризує здатність до навчання гімнастичним вправам.

Фактор 4 (інформативність 12,096\%) найбільшу кореляцію має з показниками фізичного розвитку $(0,885 ; 0,855)$. Фактор отримав назву фізичний розвиток.

Фактор 5 (інформативність 8,673 \%) має найбільшу кореляцію з показниками координації рухів: тест № 11 «Ходьба по прямій лінії після 5 обертів» $(0,761)$, тест № 10 «Час збереження стійкого положення - стійка на одній нозі з закритими очима» (-0,581). Фактор отримав назву здатність до координації рухів.

Аналіз спільностей $\left(\mathrm{h}^{2}\right)$ показав, що найбільшу інформативність для оцінки розвитку рухової функції хлопчиків третього класу має рівень розвитку власне силових здібностей: тест «Підтягування у змішаному висі на канаті (разів)» $(0,941)$, рівень навченості вправам: «Підйом переворотом в упор махом однією» $(0,910)$, «Міст із положення лежачи» $(0,860)$. Отже, у факторній моделі рухової функції у хлопців третього класу виділяються процеси навчання і розвитку силових здібностей здібностей.

Для визначення факторної моделі розвитку рухової функціїу хлопчиків 4 класу був проведений факторний аналіз за 14 показниками тестування. У процесі аналізу виділилося чотири фактори, які пояснюють 70,608 \% сумарної дисперсії.

Фактор 1 має найбільшу інформативність $(17,187 \%)$. Фактор корелює 3 рівнем навченості лазінню по канату у 2 і 3 прийоми $(0,921 ; 0,921)$. Фактор отримав назву «здатність до навчання фізичним вправам».

Фактор 2 (інформативність 16,962\%) має найбільшу кореляцію 3 результатами тестів: № 4 «Біг 300 метрів» (0,798), № 5 «Біг 30 метрів 3 високого старту» $(0,695)$, а також з показниками фізичного розвитку. Фактор отримав назву «витривалість».

Фактор 3 (інформативність 12,733 \%) має найбільшу кореляцію з результатами тестів: № 8 «Човниковий біг $4 \times 9$ метрів» $(-0,803)$, № 9 «Вправи на поєднання рухів руками, тулубом і ногами» $(0,760)$. Фактор отримав назву координаційні здібності.

Фактор 4 (інформативність 12,118\%) найбільшу кореляцію має з результатами тестів: № 10 «Час збереження стійкого положення - стійка на одній нозі з закритими очима» $(-0,800)$, № 11 «Ходьба по прямій лінії після 5 обертів» $(0,784)$. Він характеризує розвиток координаційних здібностей і доповнює фактор 3.

Фактор 5 (інформативність 11,608 \%) найбільшу кореляцію має з результатами тесту № 7 «Підтягування у змішаному висі на канаті» $(0,853)$ і рівнем 
навченості вправі «Підйом переворотом в упор махом однією» $(0,718)$.

Аналіз спільностей $\left(\mathrm{h}^{2}\right)$ показав, що найбільшу інформативність для оцінки розвитку рухової функції хлопчиків четвертого класу має рівень навченості вправам «Лазіння по канату у 2 прийоми» $(0,939)$, «Лазіння по канату у 3 прийоми» $(0,939)$, «Підйом переворотом в упор махом однією» $(0,745)$, а також результати тестів: № 7 «Підтягування у змішаному висі на канаті» $(0,787)$, № 10 «Час збереження стійкого положення - стійка на одній нозі з закритими очима» $(0,723)$. Отже, у факторній моделі рухової функції у хлопців третього класу виділяються процеси навчання і розвитку силових і координаційних здібностей.

Обговорення результатів дослідження. Наведені результати дослідження доповнюють дані Худолія О.М., Іващенко О.В., Черненко С.О. (2013), Худолія О.М., Іващенко О.В. $(2013,2014)$ про цілісність процесів розвитку рухових здібностей і формування рухових навичок у школярів молодших класів.

Отже у факторній моделі розвитку рухової функції хлопчиків молодших класів провідне місце займає рівень навченості фізичним вправам. Розвиток рухових здібностей $є$ ефективним, якщо вони стають складовою засвоєних рухових навичок. Ці дані підтверджують результати дискримінантного аналізу, проведеного Худолієм О.М., Іващенко О.В., Черненко С.О. (2013), і вказують на ефективність використання методу моделювання у вивченні закономірностей становлення рухової функції у дітей і підлітків (Арефьев В.Г., 2014; Єрмаков С.С., 2010; Худолій О.М., Марченко С.I., 2007; Худолій O.M.,
Іващенко O.B., 2014; Adashevskiy V.M., Iermakov S.S., Firsova Iu.Iu., 2013).

\section{Висновки}

У факторній моделі рухової функції у хлопців виділяються:

- процеси навчання і розвитку рухових здібностей (другий клас);

- процеси навчання і розвитку силових здібностей (третій клас);

- процеси навчання і розвитку силових і координаційних здібностей (четвертий клас).

Найбільшу інформативність для оцінки розвитку рухової функції у хлопчиків мають:

другий клас - рівень навченості акробатичних вправ $(0,848 ; 0,774 ; 0,809)$;

третій клас - рівень розвитку власне силових здібностей: тест «Підтягування у змішаному висі на канаті (разів)» $(0,941)$, рівень навченості вправам: «Підйом переворотом в упор махом однією» $(0,910)$, «Міст із положення лежачи» $(0,860)$;

четвертий клас - рівень навченості вправам «Лазіння по канату у 2 прийоми» $(0,939)$, «Лазіння по канату у 3 прийоми» $(0,939)$, «Підйом переворотом в упор махом однією» $(0,745)$, а також результати тестів: № 7 «Підтягування у змішаному висі на канаті» $(0,787)$, № 10 «Час збереження стійкого положення - стійка на одній нозі з закритими очима» $(0,723)$.

Перспективою подальших розвідок є розробка методологічних підходів до педагогічного контролю рухової підготовленості дітей і підлітків.

\section{Література}

1. Арефьев В.Г., Моделирование дифференцированной физической подготовленности школьников // Педагогика, психология и медико-биологические проблемы физического воспитания и спорта. 2014. 一№ 1. - С. 3-8. doi:10.6084/m9.figshare. 894383

2. Ашмарин Б. А. Методика педагогических исследований в физическом воспитании / Б. А. Ашмарин. — Л. : ЛГПИ им. Герцена, 1973. - 142 с.

3. Бальсевич В.К. Онтокинезиология человека / Бальсевич В.К. - М.: Теория и практика физической культуры, 2000. - 275 с.

4. Васьков Ю. В. Шляхи удосконалення навчального процесу з фізичної культури в загальноосвітніх навчальних закладах / Ю. В. Васьков // Теорія та методика фізичного виховання. -2010 . - № 6 . - С. 47-48. - Режим доступу: http://www.tmfv.com.ua/ journal/article/view/635

5. Васьков Ю. В. Моделювання методичної системи навчання фізичної культури учнів загальноосвіт-

\section{References}

1. Arefev V.G. (2014). Modelirovanie differentsirovannoy fizicheskoy podgotovlennosti shkolnikov. Pedagogika, psihologiya ta mediko-biologichni problemi fizichnogo vihovannya i sportu, (1), 3-8. doi:10.6084/ m9.figshare. 894383

2. Ashmarin B. A. (1973). Metodika pedagogicheskih issledovanij v fizicheskom vospitanii. L. : LGPI im. Gercena, 142.

3. Balsevich V.K. (2000). Ontokineziologiya cheloveka. M.: Teoriya i praktika fizicheskoy kulturyi, $275 \mathrm{c}$.

4. Vas'kov Yu. V. (2010). Shlyakhy udoskonalennya navchal'noho protsesu z fizychnoyi kul'tury v zahal'noosvitnikh navchal'nykh zakladakh. Teoria ta metodika fizicnogo vihovanna [Theory and methods of the physical education], (6), 47-48. - Rezhym dostupu: http://www.tmfv.com.ua/journal/article/view/635

5. Vas'kov Yu. V. (2012). Modelyuvannya metodychnoyi systemy navchannya fizychnoyi kul'tury uchniv zahal'noosvitnikh navchal'nykh zakladiv. Teoria ta 
ніх навчальних закладів / Ю. В. Васьков // Теорія та методика фізичного виховання. - 2012. - № 1. C. 8-11. - Режим доступу: http://www.tmfv.com.ua/ journal/article/view/761

6. Дубровский В. И. Спортивная медицина:Учебник для студентов вузов, обучающихся по педагическим спеціальностям. - 3-е изд. - М. : Гуманитар. изд. центр ВЛАДОС, 2005 - 528 с.

7. Єрмаков С. С. Біомеханічні моделі ударних рухів у спортивних іграх у контексті вдосконалення технічної підготовки спортсменів. / Єрмаков С. С. // Теорія та методика фізичного виховання. - 2010. — №4. - C. 11-18.

8. Иващенко О.В. Нормативные показатели тренировочных нагрузок на начальном этапе подготовки юных гимнасток 6-8 лет: Автореф. дис. ... канд. пед. наук. 13.00.04 / Иващенко О.В. - М.: НИИ физиологии детей и подростков, 1988. - 17 с.

9. Карпунець Т. В. Методика підготовки юних гімнасток / Т. В. Карпунець // Теорія та методика фізичного виховання. - 2001. - № 1. - С. 49-51. - Режим доступу: http://www.tmfv.com.ua/journal/article/ view/12

10. Круцевич, Т.Ю. Основні напрямки вдосконалення програм фізичного виховання школярів / Т.Ю. Круцевич // Теорія і методика фізичного виховання i спорту. - 2006. - № 4. - С. 21.

11. Круцевич Т. Ю., Безверхня Г. В. Рекреація у фізичній культурі різних груп населення: Навч. посібник / Круцевич Т. Ю., Безверхня Г. В. - К.: Олімп. л-ра, 2010. - 248 c.

12. Круцевич Т.Ю. Научные исследования в массовой физической культуре. - К.: Здоров'я, 1985. - С. $30-35$.

13. Лях В. І. Двигательные способности школьников: Основы теории и методики развития. - М.: Терра - Спорт, 2000. - 192 с.

14. Марченко С. I. Моделювання розвитку сили у школярів 2-4 класів засобами рухливих ігор / С. I. Марченко // Теорія та методика фізичного виховання. - 2010. - № 2. - С. 11-15. - Режим доступу: http:// www.tmfv.com.ua/journal/article/view/600

15. Марченко С. І. Моделювання розвитку швидкості у школярів 2-4 класів засобами рухливих ігор / C. I. Марченко // Теорія та методика фізичного виховання. - 2009. - № 10. - С. 10-14. - Режим доступу: http://www.tmfv.com.ua/journal/article/view/567

16. Марченко С. І. Характеристика впливу ігрових засобів на динаміку розвитку витривалості в учнів молодшого шкільного віку / С. І. Марченко // Теорія та методика фізичного виховання. — 2008. — № 10. - C. 38-49. - Режим доступу: http://www.tmfv.com. ua/journal/article/view/465

17. Марченко С. І. Особливості рухової підготовленості молодших школярів / С. І. Марченко // Теорія та методика фізичного виховання. — 2007. — № 5. C. 15-18, 35, 36. - Режим доступу: http://www.tmfv. com.ua/journal/article/view/307

18. Мірошниченко Д. Т. Методика навчання акробатичним вправам учнів молодших класів / Д. Т. Мірошниченко // Теорія та методика фізичного вихован- metodika fizicnogo vihovanna [Theory and methods of the physical education], (1), 8-11. - Rezhym dostupu: http://www.tmfv.com.ua/journal/article/view/761

6. Dubrovskij V. I. (2005). Sportivnaja medicina: Uchebnik dlja studentov vuzov, obuchajushhihsja po pedagicheskim special'nostjam. 3-e izd. M. : Gumanitar. izd. centr VLADOS, 528.

7. Iermakov S. S. (2010). Biomekhanichni modeli udarnykh rukhiv u sportyvnykh ihrakh u konteksti vdoskonalennya tekhnichnoyi pidhotovky sport.smeniv. Teoria ta metodika fizicnogo vihovanna [Theory and methods of the physical education], (4), 11-18.

8. Ivashhenko O.V. (1988). Normativnye pokazateli trenirovochnyh nagruzok na nachal'nom jetape podgotovki junyh gimnastok 6-8 let: Avtoref. dis. ... kand. ped. nauk. 13.00.04. M.: NII fiziologii detej i podrostkov, 17

9. Карпунець Т. В. (2001). Методика підготовки юних гімнасток. Teoria ta metodika fizicnogo vihovanna [Theory and methods of the physical education], (1), 49-51. - Rezhym dostupu: http://www.tmfv.com.ua/ journal/article/view/12

10. Krutsevych, T.Yu. (2006). Osnovni napryamky vdoskonalennya prohram fizychnoho vykhovannya shkolyariv. Teoriya i metodyka fizychnoho vykhovannya i sportu, (4), 21.

11. Krutsevich T. Yu. \& Bezverhnya G. V. (2010).Rekreatsiya u fizichniy kulturi riznih grup naselennya: Navch. posibnik. K.: Olimp. 1-ra, 248.

12. Krucevich T.Ju. (1985). Nauchnye issledovanija v massovoj fizicheskoj kul'ture. K.: Zdorov'ja, 30-35.

13. Ljah V. I. (2000). Dvigatel'nye sposobnosti shkol'nikov: Osnovy teorii i metodiki razvitija. M.: Terra - Sport, 192.

14. Marchenko S. I. (2010). Modelyuvannya rozvytku syly u shkolyariv 2-4 klasiv zasobamy rukhlyvykh ihor. Teoria ta metodika fizicnogo vihovanna [Theory and methods of the physical education], (2), 11-15. Rezhym dostupu: http://www.tmfv.com.ua/journal/ article/view/600

15. Marchenko S. I. (2009). Modelyuvannya rozvytku shvydkosti u shkolyariv 2-4 klasiv zasobamy rukhlyvykh ihor. Teoria ta metodika fizicnogo vihovanna [Theory and methods of the physical education], (10), 10-14. - Rezhym dostupu: http://www.tmfv.com.ua/ journal/article/view/567.

16. Marchenko S. I. (2008). Kharakterystyka vplyvu ihrovykh zasobiv na dynamiku rozvytku vytryvalosti v uchniv molodshoho shkil'noho viku. Teoria ta metodika fizicnogo vihovanna [Theory and methods of the physical education], (10), 38-49. - Режим доступу: http://www.tmfv.com.ua/journal/article/view/465

17. Marchenko S. I. (2007). Osoblyvosti rukhovoyi pidhotovlenosti molodshykh shkolyariv. Teoria ta metodika fizicnogo vihovanna [Theory and methods of the physical education], (5), 15-18, 35-36. - Rezhym dostupu: http://www.tmfv.com.ua/journal/article/ view/307

18. Miroshnychenko D. T. (2007). Metodyka navchannya akrobatychnym vpravam uchniv molodshykh klasiv. Teoria ta metodika fizicnogo vihovanna [Theory and methods of the physical education], (12), 29-31. - 
ня. - 2007. - № 12. - С. 29-31. - Режим доступу: http://www.tmfv.com.ua/journal/article/view/380

19. Москаленко, Н. В. Система заходів по формуванню знань з основ здорового способу життя у загальноосвітніх навчальних закладах / Москаленко Н. В., Гонтаровська Н.Б. // Педагогіка, психологія та медико-біологічні проблеми фізичного виховання і спорту: зб. наук. пр. - Харків: ХДАДМ (ХХПІ), 2006. - № 1. - С. 112-116.

20. Носко М.О. Вікові особливості фізичного розвитку школярів, які займаються спортом // Педагогіка, психологія та медико-біологічні проблеми фізичного виховання і спорту: 3б. наук. праць під ред. Єрмакова С.С. - Харків: XXII, 2001, — № 7, - С. 3-7.

21. Сергієнко Л. П. Тестування рухових здібностей школярів. - К.: Олімпійська література, $2001-439$ с.

22. Филин В.П. Методы исследования в спорте: Учебное пособие / В.П. Филин, А.С. Ровний. - Харьков: Основа, 1992. - С. 63-68.

23. Худолій, О. М. Моделювання розвитку швидкісносилових здібностей у школярів 2-4 класів засобами рухливих ігор / Худолій, О. М., С. І. Марченко // Педагогіка, психологія та медико-біологічні проблеми фізичного виховання і спорту: зб. наук. пр. за ред. Єрмакова С.С. -2007. - № 8. - С. 139-142.

24. Худолій О. М. Особливості розвитку швидкісної сили у школярів молодших класів / О. М. Худолій, О. В. Іващенко, Д. Т. Мірошниченко // Теорія та методика фізичного виховання. - 2012. — № 10. - C. 3-8. — DOI:http://dx.doi.org/10.17309/ tmfv.2012.10.825

25. Худолій О. М. Інформаційне забезпечення процесу навчання і розвитку рухових здібностей дітей і підлітків (на прикладі спортивної гімнастики) / Худолій О. М., Іващенко О. В. // Теорія та методика фізичного виховання. - Харків: ОВС, 2013. № 4. - C. 3-18. DOI: http://dx.doi.org/10.17309/ tmfv.2013.4.1031

26. Худолій О. М. Особливості розвитку рухових здібностей у хлопчиків молодшого шкільного віку / О. М. Худолій, А. А. Тітаренко // Теорія та методика фізичного виховання. - 2010. - № 8. - С. 3-12. DOI:http://dx.doi.org/10.17309/tmfv.2010.8.644

27. Худолій O.М., Чинники, що впливають на ефективність навчання фізичним вправам хлопчиків молодших класів / Худолій О.М., Іващенко О.В., Черненко С.О. // Теорія та методика фізичного виховання. - 2013. - № 1. - C. 21-26. DOI: http:// dx.doi.org/10.17309/tmfv.2013.1.1006

28. Худолій О. М. Технологія навчання гімнастичним вправам / О. М. Худолій // Теорія та методика фізичного виховання. - 2009. - № 9. - С. 19-34. DOI:http://dx.doi.org/10.17309/tmfv.2009.9.562

29. Худолій О.М., Концептуальні підходи до моделювання процесу навчання і розвитку рухових здібностей у дітей і підлітків / Худолій О.М., Іващенко О.В. // Теорія та методика фізичного виховання. - 2013. - № 2. - C. 3-16. DOI: http://dx.doi. org/10.17309/tmfv.2013.2.1012

30. Худолій О. М. Педагогічна практика в школі. Повідомлення II / О. М. Худолій, О. В. Іващенко // Теорія та методика фізичного виховання. - 2011. -
Rezhym dostupu: http://www.tmfv.com.ua/journal/ article/view/380

19. Moskalenko, N. V. \& Hontarovs'ka N.B. (2006). Systema zakhodiv po formuvannyu znan' $\mathrm{z}$ osnov zdorovoho sposobu zhyttya u zahal'noosvitnikh navchal'nykh zakladakh. Pedagogika, psihologiya ta medikobiologichni problemi fizichnogo vihovannya i sportu, (1), 112-116.

20. Nosko M.O. (2001). Vikovi osoblyvosti fizychnoho rozvytku shkolyariv, yaki zaymayut'sya sportom. Pedagogika, psihologiya ta mediko-biologichni problemi fizichnogo vihovannya i sportu, (7), 3-7.

21. Serhiyenko L. P. (2001). Testuvannya rukhovykh zdibnostey shkolyariv. K.: Olimpiys'ka literatura, 439.

22. Filin V.P., \& Rovnij A.S. (1992). Metody issledovanija v sporte: Uchebnoe posobie. Har'kov: Osnova, 63-68.

23. Khudolii, O., \& Marchenko, S. (2007). Modelyuvannya rozvytku shvydkisno-sylovykh zdibnostey u shkolyariv 2-4 klasiv zasobamy rukhlyvykh ihor. Pedagogika, psihologiya ta mediko-biologichni problemi fizichnogo vihovannya i sportu, (8), 139-142.

24. Khudolii O. M., Ivashchenko O.V. \& Miroshnychenko D.T. (2012). Osoblyvosti rozvytku shvydkisnoyi syly u shkolyariv molodshykh klasiv. Teoria ta metodika fizicnogo vihovanna [Theory and methods of the physical education], (10), 3-8. - DOI:http://dx.doi. org/10.17309/tmfv.2012.10.825

25. Khudolii O. M., \& Ivashchenco O. V. (2013). Informatsiyne zabezpechennya protsesu navchannya i rozvitku ruhovih zdibnostey ditey i pidlitkiv (na prikladi sportivnoyi gimnastiki). Teoria ta metodika fizicnogo vihovanna [Theory and methods of the physical education], (4), 3-18. DOI: http://dx.doi. org/10.17309/tmfv.2013.4.1031

26. Khudolii O. M. \& Titarenko A.A. (2010). Osoblyvosti rozvytku rukhovykh zdibnostey u khlopchykiv molodshoho shkil'noho viku. Teoria ta metodika fizicnogo vihovanna [Theory and methods of the physical education], (8), 3-12. - DOI:http://dx.doi. org/10.17309/tmfv.2010.8.644

27. Khudolii O.M., Ivashchenko O.V., \& Chernenko S.O. (2013). Chinniki, scho vplivayut na efektivnist navchannya fizichnim vpravam hlopchikiv molodshih klasiv. Teoria ta metodika fizicnogo vihovanna [Theory and methods of the physical education], (1), 21-26. DOI:http://dx.doi.org/10.17309/tmfv.2013.1.1006

28. Khudoliy O. M. (2009). Tekhnolohiya navchannya himnastychnym vpravam. Teoria ta metodika fizicnogo vihovanna [Theory and methods of the physical education], (9), 19-34. - DOI:http://dx.doi. org/10.17309/tmfv.2009.9.562

29. KhudoliiO.M.,\&IvashchencoO.V.(2013).Kontseptualni pidhodi do modelyuvannya protsesu navchannya i rozvitku ruhovih zdibnostey u ditey i pidlitkiv. Teoria ta metodika fizicnogo vihovanna [Theory and methods of the physical education], (10), 3-16. DOI: http://dx.doi. org/10.17309/tmfv.2013.2.1012

30. Khudoliy O.M. \& Ivashchenko O.V. (2011). Pedahohichna praktyka v shkoli. Povidomlennya II. Teoria ta metodika fizicnogo vihovanna [Theory and methods of the physical education], (9), 19-32. DOI:http://dx.doi.org/10.17309/tmfv.2011.9.740 
№ 9. - C. 19-32. - DOI:http://dx.doi.org/10.17309/ tmfv.2011.9.740

31. Худолій О.М. Моделювання процесу навчання та розвитку рухових здібностей у дітей і підлітків: Монографія / Худолій О.М., Іващенко О.В. - Харків: OBC, 2014. - $320 \mathrm{c}$.

32. Adashevskiy V.M., Iermakov S.S., Firsova Iu.Iu., Physical mathematical modelling of difficult elements of acrobatic rock-and-roll. Physical Education of Students, 2013, vol.3, pp. 3-10. doi:10.6084/m9.figshare.662463

33. Matthews Tracey. Physical activity levels and attitudes toward physical activity and eating habits in an urban elementary school setting / Tracey Matthews, Elizabeth Oneill, Kimberly Kostelis // Journal of Physical Education and Sport (JPES). - 2014. - Vol 14. - Issue 1. - Art 3. - Pp. 16-21. DOI:10.7752/jpes.2014.01003

34. Martins Júlio. Students' motivation to practice sports in school between 9 to 14 years of basic education / Martins Júlio, Honório Samuel, Cardoso João, Duarte Luís // Journal of Physical Education and Sport (JPES). - 2014. - Vol 14. - Issue 4. - Art 70. - Pp. 459470. DOI:10.7752/jpes.2014.04070

35. Cieślicka M., Muszkieta R., Napierała M., Żukow W. Aktywność ruchowa młodzieży w Gnieźnie. [w:] (Red.) Marek Napierała, Radosław Muszkieta, Walery Żukow. Człowiek - rekreacja -zdrowie. WSG Bydgoszcz. 2009. 24-39.

36. Cieślicka M., Dix B., Napierała M., Żukow W. Physical activity of young people from the junior secondary school No. 35 in Bydgoszcz. W: Health- the proper functioning of man in all spheres of life, Vol III, Bydgoska Szkoła Wyższa, Bydgoszcz 2012, 175-189

37. Coskun Ali. Two different strength training and untrained period effects in children /Ali Coskun, Gulsah Sahin // Journal of Physical Education and Sport (JPES). - 2014. - Vol 14. - Issue 1. - Art 7. - Pp. 42-46. DOI:10.7752/jpes.2014.01007

38. Panagiotis Veligekas. Bilateral deficit in vertical jumping in pre-pubertal boys and girls / Panagiotis Veligekas \& Gregory C. Bogdanis // Journal of Physical Education and Sport (JPES). - 2013. - Vol 13. - Issue 4. - Art 20. - Pp. 120-126. DOI:10.7752/jpes.2013.01020

39. Piccinno Andrea. Physical fitness level in Italian highschool adolescents: a cross-sectional study / Andrea Piccinno, Dario Colella // Journal of Physical Education and Sport (JPES). - 2014. - Vol 14. - Issue 3. - Art 7. - Pp. 431-437. DOI:10.7752/jpes.2014.03066
31. Khudolii O. M., \& Ivashchenco O. V. (2014) Modelyuvannya protsesu navchannya ta rozvitku ruhovih zdibnostey u ditey i pidlitkiv: Monografiya. Kharkiv: OVS, 320.

32. Adashevskiy V.M., Iermakov S.S., Firsova Iu.Iu., Physical mathematical modelling of difficult elements of acrobatic rock-and-roll. Physical Education of Students, 2013, vol.3, pp. 3-10. doi:10.6084/m9.figshare. 662463

33. Matthews Tracey. Physical activity levels and attitudes toward physical activity and eating habits in an urban elementary school setting / Tracey Matthews, Elizabeth Oneill, Kimberly Kostelis // Journal of Physical Education and Sport (JPES). - 2014. - Vol 14. - Issue 1. - Art 3. - Pp. 16-21. DOI:10.7752/jpes.2014.01003

34. Martins Júlio. Students' motivation to practice sports in school between 9 to 14 years of basic education / Martins Júlio, Honório Samuel, Cardoso João, Duarte Luís // Journal of Physical Education and Sport (JPES). - 2014. - Vol 14. - Issue 4. - Art 70. - Pp. 459470. DOI:10.7752/jpes.2014.04070

35. Cieślicka M., Muszkieta R., Napierała M., Żukow W. Aktywność ruchowa młodzieży w Gnieźnie. [w:] (Red.) Marek Napierała, Radosław Muszkieta, Walery Żukow. Człowiek - rekreacja -zdrowie. WSG Bydgoszcz. 2009. 24-39.

36. Cieślicka M., Dix B., Napierała M., Żukow W. Physical activity of young people from the junior secondary school No. 35 in Bydgoszcz. W: Health- the proper functioning of man in all spheres of life, Vol III, Bydgoska Szkoła Wyższa, Bydgoszcz 2012, 175-189

37. Coskun Ali. Two different strength training and untrained period effects in children /Ali Coskun, Gulsah Sahin // Journal of Physical Education and Sport (JPES). - 2014. - Vol 14. - Issue 1. - Art 7. - Pp. 42-46. DOI:10.7752/jpes.2014.01007

38. Panagiotis Veligekas. Bilateral deficit in vertical jumping in pre-pubertal boys and girls / Panagiotis Veligekas \& Gregory C. Bogdanis // Journal of Physical Education and Sport (JPES). - 2013. - Vol 13. - Issue 4. - Art 20. - Pp. 120-126. DOI:10.7752/jpes.2013.01020

39. Piccinno Andrea. Physical fitness level in Italian highschool adolescents: a cross-sectional study / Andrea Piccinno, Dario Colella // Journal of Physical Education and Sport (JPES). - 2014. - Vol 14. - Issue 3. - Art 7. - Pp. 431-437. DOI:10.7752/jpes.2014.03066 


\title{
ФАКТОРНАЯ МОДЕЛЬ РАЗВИТИЯ ДВИГАТЕЛЬНОЙ ФУНКЦИИ У МАЛЬЧИКОВ МЛАДШИХ КЛАССОВ
}

\author{
Мирошниченко Д. Т. \\ Харьковский национальный экономический университет \\ Реферат. Статья: 8 с., 4 табл., 39 источники.
}

\begin{abstract}
Цель исследования - определить факторную модель развития двигательной функции у мальчиков младших классов. Методы и организация исследования. В исследовании использованы такие методы исследования как анализ научной и методической литературы, педагогические наблюдения, тестирование двигательной подготовленности, вероятностный подход к оценке процесса обучения, методы математической статистики. В исследовании приняли участие мальчики 2 класса - 38 человек, 3 класса - 42 человек, 4 класса -48 человек.

Выводы. В факторной модели двигательной функции у мужчин выделяются: процессы обучения и развития двигательных способностей (второй класс); процессы обучения и развития силовых способностей (третий класс); процессы обучения и развития силовых и координационных способностей (четвертый класс).
\end{abstract}

Наибольшую информативность для оценки развития двигательной функции у мальчиков имеют: второй класс - уровень обученности акробатических упражнений $(0,848 ; 0,774 ; 0,809)$ третий класс - уровень развития собственно силовых способностей: тест «Подтягивание в смешанном висе на канате (раз)» $(0,941)$, уровень обученности упражнениям: «Подъем переворотом в упор махом одной» $(0,910)$, «Мост из положения лежа» $(0,860)$ ; четвертый класс - уровень обученности упражнениям «Лазанья по канату в 2 приема» $(0,939)$, «Лазанья по канату в 3 приема» $(0,939)$, «Подъем переворотом в упор махом одной» $(0,745)$, а также результаты тестов: № 7 «Подтягивание в смешанном висе на канате» $(0,787)$, № 10 «Время сохранения устойчивого положения - стойка на одной ноге с закрытыми глазами» $(0,723)$.

Ключевые слова. Мальчики, младшие классы, обучение, физические упражнения.

\section{FACTOR MODEL OF MOTOR FUNCTION IN BOYS JUNIOR}

\author{
Miroshnichenko D.T. \\ Kharkiv National University of Economics \\ Report. Article: 8 p., 4 tables., 39 sources
}

The aim - to determine the factor model of motor function in boys junior. Methods and organization studies. The study used research methods such as analysis of the scientific and technical literature, pedagogical supervision, testing motor training, probabilistic approach to the assessment of the learning process, methods of mathematical statistics. In the study involved boys Class $2-38$ people, Class $3-42$ people, Class $4-48$ people.

Conclusions. In the factor model of motor function in males are: learning and development of motor skills (second class); learning and development of power abilities (third grade); learning and development of power and coordination abilities (fourth class).
The most informative for assessment of motor function in boys with: second class - the level of training of acrobatic exercises $(0.848 ; 0.774 ; 0.809)$; third grade the level of development of the security capabilities: test "Pulling in mixed Wiese on the rope (times)" (0.941), the level of training exercises: "The rise of revolution in focus stroke one" (0.910), "Most of the prone position" $(0.860)$; fourth grade - the level of training exercises "Climbing the rope in 2 hours" (0.939), "Climbing the rope in 3 hours" (0.939), "The rise of revolution in focus stroke one" (0.745), and the test results: № 7 " Pulling in mixed Wiese on the rope »(0,787), № $10 "$ Time saving sustainable position stand on one leg with eyes closed "(0.723).

Keywords. Boys younger classes, training, exercise.

Інформація про авторів:

Мірошниченко Д.Т.: Харківський національний економічний університет імені Семена Кузнеця, м. Харків, 61002 , Україна.

Цитуйте статтю як: Мірошниченко Д.Т. Факторна модель розвитку рухової функції у хлопчиків молодших класів / Мірошниченко Д.Т. // Теорія та методика фізичного виховання. - 2014. - № 4. - C. 23-31. DOI: http://dx.doi. org/10.17309/tmfv.2014.4.1114

Стаття надійшла до редакції: 05.11.2014 р. Прийнята: 15.12.2014. Надрукована: 25.12.2014

丁以门SB. -2014 . - № 04 